\title{
Green turtle nesting on Trindade Island, Brazil: abundance, trends, and biometrics
}

\author{
Antonio de Padua Almeida ${ }^{1, *}$, Luciana M. P. Moreira ${ }^{1,2}$, Soraya Christina Bruno ${ }^{3}$, \\ João Carlos A. Thomé ${ }^{1}$, Agnaldo S. Martins ${ }^{2,4}$, Alan B. Bolten ${ }^{5}$, Karen A. Bjorndal ${ }^{5}$ \\ ${ }^{1}$ Projeto TAMAR-ICMBio, Cx Postal 105, Linhares, ES 29900-970, Brazil \\ ${ }^{2}$ Universidade Federal do Espírito Santo, Programa de Pós-graduação em Ciências Biológicas. Av. Marechal Campos, 1468, \\ Maruípe, Vitória, ES 29040-090, Brazil \\ ${ }^{3}$ Fundação Pró-TAMAR, Av. Paulino Miller, m 1111, Jucutuquara, Vitória, ES 29040-715, Brazil \\ ${ }^{4}$ Universidade Federal do Espírito Santo, Programa de Pós-graduação em Oceanografia Ambiental, Av. Fernando Ferrari, \\ 514, Campus de Goiabeiras, Vitória, ES 29075-910, Brazil \\ ${ }^{5}$ Archie Carr Center for Sea Turtle Research and Department of Biology, University of Florida, Gainesville, \\ Florida 32611, USA
}

\begin{abstract}
Green turtles Chelonia mydas nesting at Trindade Island, $1140 \mathrm{~km}$ off the coast of Brazil, were monitored discontinuously from 1982/83 to 2008/09. For 7 years during this period, the majority of nesting was monitored, and the number of nests deposited on Trindade varied from 1333 to 5261. Based on these nest counts, Trindade is among the most important known Atlantic nesting sites for green turtles. The population remained stable between 1991 and 2008. Data on female body size, clutch size, internesting intervals, remigration intervals, and hatching success are also presented.
\end{abstract}

KEY WORDS: Sea turtle $\cdot$ Chelonia mydas $\cdot$ Nesting $\cdot$ Biometrics $\cdot$ Atlantic Ocean $\cdot$ Brazil · Trindade $\cdot$ Population size

\section{INTRODUCTION}

Our understanding of the relative importance of sea turtle populations is a dynamic process, modified as new nesting areas are evaluated (Bourjea et al. 2007, Lauret-Stepler et al. 2007). The green turtle Chelonia mydas rookery on Trindade Island, Brazil, is one of the last major rookeries in the Atlantic to be characterized. Abundance estimates, population trends, and biometric parameters have been published for other major Atlantic green turtle populations, such as Tortuguero, Costa Rica; Ascension Island, UK; Aves Island, Venezuela; Suriname; and Florida, USA (Schulz 1975, Bjorndal \& Carr 1989, Penaloza 2000, Godley et al. 2001, 2002, Seminoff 2004, Troëng \& Rankin 2005, Broderick et al. 2006, Chaloupka et al. 2008).
The green turtle is the most abundant species recorded in stranding records along the Brazilian coast (Gallo et al. 2006), and flipper tags have revealed that green turtles foraging in Brazilian waters are derived from different nesting populations (Carr 1975, Lima \& Troëng 2001). Except for a few nests recorded annually at nesting beaches in the state of Bahia, a major loggerhead Caretta caretta nesting ground in northeastern Brazil (Marcovaldi \& Chaloupka 2007), the green turtle nesting areas in Brazil are restricted to the oceanic islands of Trindade, Atol das Rocas, and Fernando de Noronha (Moreira et al. 1995, Bellini et al. 1996, Bellini \& Sanches 1996, Marcovaldi \& Marcovaldi 1999). Significant genetic structure exists among the 3 rookeries. Based on mtDNA haplotype frequencies, Trindade is significantly different from the other 2 
rookeries, but Atol das Rocas and Fernando de Noronha are not significantly different from each other (Bjorndal et al. 2006). These rookeries have been monitored by Projeto TAMAR-ICMBio (the sea turtle conservation program of the Brazilian environmental agency) since 1982 (Filippini \& Bulhões 1988, Marcovaldi \& Marcovaldi 1999). Although the annual numbers of nests at these sites made it clear that Trindade is the main green turtle nesting ground in Brazil (Moreira et al. 1995), there are no estimates of the rookery size at Trindade. Here, we estimated the annual number of nests and females, evaluated the trend in nesting numbers, and present biometric data for green turtles nesting on Trindade.

\section{MATERIALS AND METHODS}

\section{Study area}

Trindade Island $\left(20^{\circ} 30^{\prime} \mathrm{S}, 2^{\circ} 20^{\prime} \mathrm{W}\right)$ is on the eastern end of the Vitória-Trindade Submarine Ridge, $1140 \mathrm{~km}$ off the coast of the state of Espírito Santo, southeastern Brazil (Fig. 1). The island is $13.5 \mathrm{~km}^{2}$ in area and is almost totally composed of volcanic and subvolcanic rocks formed between the end of the Pliocene and the Holocene (Almeida 2002). The coastline consists of algae reefs, narrow beaches, and narrow dunes. The entire extent of the Vitória-Trindade chain is under the influence of the southward flow of the warm Brazil Current (Miranda \& Castro Filho 1982). A tropical oceanic climate prevails, ameliorated by eastern and southern trade winds, with mean water temperatures of $27^{\circ} \mathrm{C}$ (DHN 1968). Air temperature is warmest in February and coldest in August (Alves 1998). An almost daily rain, lasting about 5 min, is called 'Pirajá.' Between April and October, cold fronts from Antarctica periodically reach the island (DHN 1968). Green turtles nest on 9 beaches (from 50 to $780 \mathrm{~m}$ long), which have varying degrees of rocky barriers that can prevent turtles from reaching the sandy areas to dig their egg chambers. The only human inhabitants on Trindade are personnel of the Brazilian Navy, which maintains a base on the island and provides protection for the nesting green turtles. Trindade has been under the control of the Brazilian Navy since 1957, well before the beginning of sea turtle monitoring on the island and can only be visited with permission from the Navy.

\section{Surveys}

Surveys were conducted during 17 non-consecutive nesting seasons, from 1982 to 2009, with large differences in patrol efforts, both temporal and spatial (Table 1). Different expeditions had distinct goals (tagging females, assessing hatching success, mapping emergences both spatially and temporally, or estimating the proportion of nests in relation to the total tracks). Consequently, types of data collected varied among the 17 seasons. Two beaches (Tartarugas and Andradas) were patrolled in all nesting seasons; systematic track counts were not recorded in 1982/ 83, 1989/90,1997/98, 2000/01, 2001/02, and 2002/03.

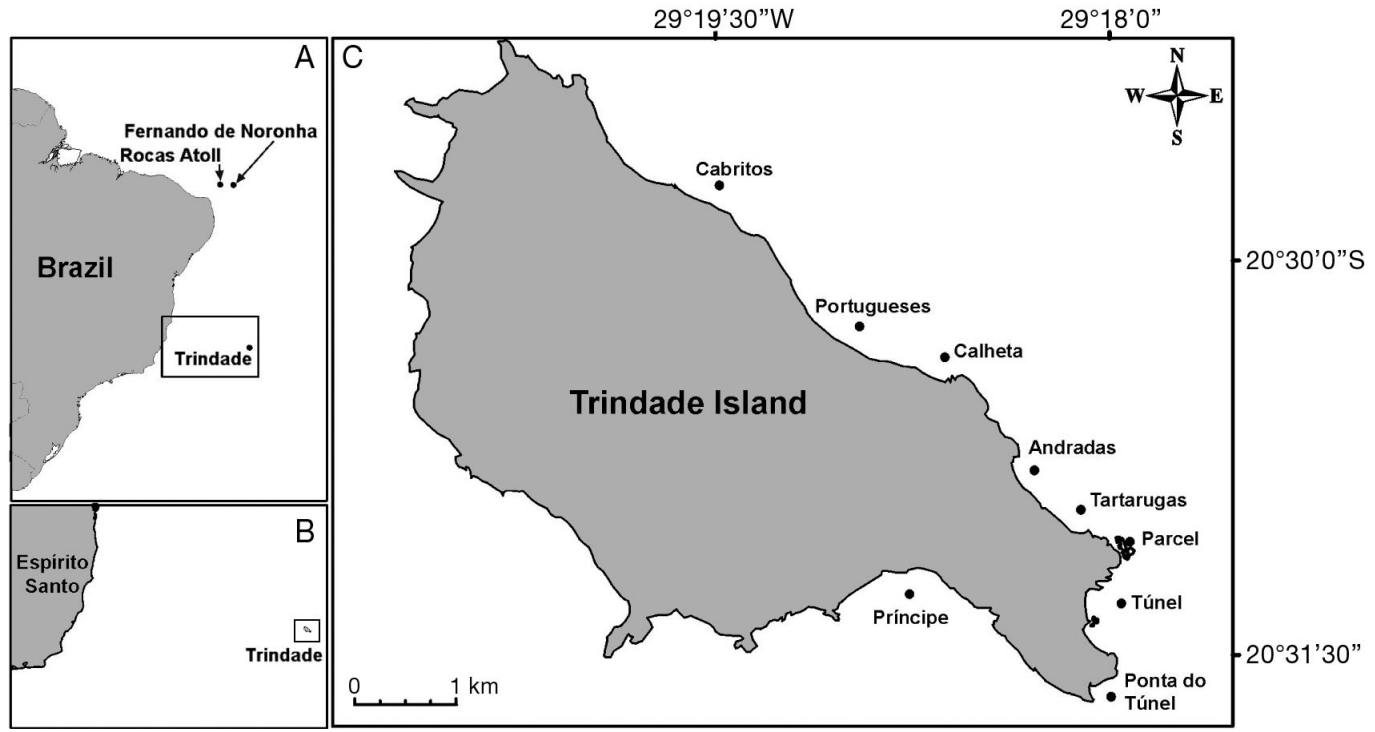

Fig. 1. Study area with the locations of the 9 nesting beaches on Trindade Island 
Table 1. Chelonia mydas. Number of beaches surveyed and tracks counted, and sampling and nesting periods recorded on Trindade Island in different nesting seasons between 1982 and 2009. Seasons in bold were used for analysis of nesting trends. The total number of tracks does not reflect relative abundance among years because temporal and spatial sampling effort varied among years; in some years, effort was directed to tagging nesting females rather than counting tracks. The entire nesting period was determined only for the last 3 seasons. Dates are shown in $\mathrm{dd} / \mathrm{mm} / \mathrm{yy}$

\begin{tabular}{|c|c|c|c|c|c|c|c|}
\hline Season & $\begin{array}{c}\text { No. of } \\
\text { beaches }\end{array}$ & $\begin{array}{l}\text { Survey dates } \\
\text { (dd/mm/yy) }\end{array}$ & $\begin{array}{l}\text { Date first nest } \\
\text { seen }(\mathrm{dd} / \mathrm{mm})\end{array}$ & $\begin{array}{l}\text { Date last nest } \\
\text { seen }(\mathrm{dd} / \mathrm{mm})\end{array}$ & $\begin{array}{l}\text { Sampling } \\
\text { period (d) }\end{array}$ & $\begin{array}{l}\text { Nesting } \\
\text { period (d) }\end{array}$ & $\begin{array}{c}\text { Total track } \\
\text { counts }\end{array}$ \\
\hline $1982 / 83$ & 2 & $17 / 12 / 82-14 / 2 / 83$ & $17 / 12$ & $14 / 2$ & 59 & - & 351 \\
\hline $1985 / 86$ & 7 & $18 / 2 / 86-12 / 4 / 86$ & $18 / 2$ & $12 / 4$ & 53 & - & 722 \\
\hline $1989 / 90$ & 4 & $13 / 3 / 90-17 / 3 / 90$ & $13 / 3$ & $17 / 3$ & 4 & - & 122 \\
\hline $1991 / 92$ & 7 & $19 / 1 / 92-26 / 5 / 92$ & $19 / 1$ & $26 / 5$ & 127 & - & 3008 \\
\hline $1993 / 94$ & 5 & $11 / 4 / 94-20 / 7 / 94$ & $11 / 4$ & $20 / 7$ & 100 & - & 506 \\
\hline $1994 / 95$ & 7 & $26 / 10 / 94-1 / 7 / 95$ & $26 / 10$ & $1 / 7$ & 249 & - & 3943 \\
\hline $1995 / 96$ & 2 & $06 / 10 / 95-23 / 5 / 96$ & $06 / 10$ & $23 / 5$ & 230 & - & 5478 \\
\hline $1996 / 97$ & 2 & $14 / 12 / 96-13 / 2 / 97$ & $14 / 12$ & $13 / 2$ & 61 & - & 1184 \\
\hline $1997 / 98$ & 2 & $2 / 1 / 98-11 / 2 / 98$ & $2 / 1$ & $11 / 2$ & 40 & - & 39 \\
\hline $1998 / 99$ & 9 & $5 / 12 / 98-13 / 2 / 99$ & $5 / 12$ & $13 / 2$ & 70 & - & 2014 \\
\hline $1999 / 2000$ & 9 & $5 / 12 / 99-4 / 4 / 00$ & $5 / 12$ & $4 / 4$ & 121 & - & 10417 \\
\hline $2000 / 01$ & 2 & $10 / 12 / 00-12 / 12 / 00$ & $10 / 12$ & $12 / 12$ & 2 & - & 2 \\
\hline $2001 / 02$ & 4 & $18 / 2 / 02-2 / 3 / 02$ & $18 / 2$ & $2 / 3$ & 12 & - & 499 \\
\hline $2002 / 03$ & 2 & $17 / 2 / 03-20 / 2 / 03$ & $17 / 2$ & $20 / 2$ & 3 & - & 33 \\
\hline $2006 / 07$ & 9 & $01 / 10 / 06-30 / 9 / 07$ & $15 / 12$ & $22 / 6$ & 365 & 190 & 9602 \\
\hline $2007 / 08$ & 9 & $01 / 10 / 07-30 / 9 / 08$ & $14 / 11$ & $15 / 6$ & 365 & 214 & 3551 \\
\hline $2008 / 09$ & 9 & $01 / 10 / 08-30 / 9 / 09$ & $21 / 10$ & $01 / 7$ & 365 & 254 & 5696 \\
\hline
\end{tabular}

Surveys comprised essentially the entire duration of the nesting season in 6 nesting seasons: 1994/95, 1995/96, 1999/2000, 2006/07, 2007/08, and 2008/09. Patrols were conducted by 2 persons on foot, at night, for tagging and measuring females, and during the day, for counting and classifying tracks as nesting or non-nesting emergences. Due to the high number of emergences, not all nesting females were intercepted on the beach. In addition, track identification was sometimes difficult because large numbers of turtles nesting on small beaches caused considerable overlap of tracks, and sometimes nests were destroyed by other females digging their nests. Therefore, the proportion of emergences corresponding to nests is only known with certainty in 4 seasons, when this information was determined for the main nesting beaches (see 'Estimation of nest numbers per season').

When a female green turtle was encountered on a nesting beach, a monel or inconel tag (no. 681 National Tag and Band Co.) was applied to the trailing edge of each front flipper. Curved carapace length (CCL) was measured from the anterior point at midline (nuchal scute) to the posterior tip of the supracaudals (notch to tip; Bolten 1999). Measurements were taken with a flexible tape measure and recorded to the nearest $0.5 \mathrm{~cm}$. Only 1 measurement for each female was used in each season.

Clutch size and hatching success were determined following standard procedures (Miller 1999). Clutch size was estimated by piecing egg shells together after hatchlings had emerged from the nest. Individual females were not associated with the clutches, so we could not relate body size and clutch size. During 4 seasons (1985/1986, 1993/1994, 1994/1995, and 1995/1996), hatching success was determined for some nests that were identified by observing tracks left by hatchlings emerging from the nest. Hatching success was calculated as the number of hatchlings that hatched out of their egg shell (= the number of empty egg shells in the nest) divided by the total number of eggs in the nest. Hatching success was determined for nests on 2 beaches: Andradas and Tartarugas.

\section{Estimation of nest numbers per season}

Annual numbers of nests were estimated for those seasons during which temporal coverage comprised at least the middle (peak) of the season and either the beginning or end of the season (1991/92, 1994/95, 1995/96, 1999/2000, 2006/07, 2007/08, and 2008/09). To estimate the annual numbers of nests deposited on Trindade, we had to develop 2 correction factors. First, because in some years only total tracks were counted without distinguishing between nesting and non-nesting emergences, we needed a correction factor to convert track counts to nest counts. Second, because not all beaches were patrolled in all years, another correction factor was needed to convert the 
number of nests on the 2 beaches that were patrolled each year, Tartarugas and Andradas, to the number of nests deposited on all beaches.

We developed the first correction factor by using data from 4 nesting seasons (1999/2000, 2006/07, 2007/08, and 2008/09) during which specific surveys were conducted to determine the proportion of emergences that resulted in nests being deposited on the 2 beaches (Tartarugas and Andradas) which have the greatest nesting activity. One night each week, from 18:30 to $06: 30 \mathrm{~h}$, patrols recorded the proportion of emergences that resulted in nests. Emerging females were carefully followed, and the emergences were classified as nesting or non-nesting emergences. Daily patrols were conducted from $5: 30$ to $11: 00 \mathrm{~h}$ and from 16:30 to $18: 30 \mathrm{~h}$ to count and obliterate the tracks to avoid including them in subsequent counts. The mean proportions of nests to total tracks calculated for the 2 main beaches ( 0.55 for Tartarugas and 0.37 for Andradas) were then used to convert the number of tracks counted on daily patrols to nest counts on those 2 beaches in earlier seasons (1991/ 92, 1994/95, and 1995/96).

The annual numbers of nests deposited on the 2 main beaches (Tartarugas and Andradas) were estimated following the technique used by Bjorndal et al. (1999). The number of nests was plotted for each day of the season, and the total number of nests for the season was approximated by fitting a cubic smoothing spline ('smooth') to each time series, using the generalized additive model function, gam() of S-plus software (version 7.0.3). Based on nest distribution patterns, 15 November and 30 May were selected as the end points of the nesting season, and a value of 0 nests was assigned to each end point. We differentially weighted the actual count values $(=1)$ and the set end points $(=0.1)$, with the exception of the 15 November 1991 endpoint, which was given a weight of 1.0 to anchor the curve because there were no data for the beginning of the season.

We developed the second correction factor, to convert the annual number of nests on Tartarugas and Andradas to the total annual number of nests on Trindade, by dividing the nest totals for Tartarugas and Andradas by the proportion of all nests laid on Trindade that are deposited on Tartarugas and Andradas (0.54). This proportion was estimated from the 3 seasons (1999/2000, 2006/07, and 2007/08) during which daily patrols covered all 9 beaches with nesting activity.

To determine whether there was a trend in nest numbers over the years of our study, we used a least squares linear regression model with log link and autoregression (order 1) error structure to account for any temporal correlation. We used S-plus software (version 7.0.3) for all statistical analyses. For all analyses, alpha $=0.05$.

\section{RESULTS}

\section{Abundance and trends}

Beginning in 1982, nests were recorded on 9 beaches on the Island (Fig. 1), although coverage varied greatly among years both spatially and temporally (Table 1). In the 6 seasons with broad temporal coverage, more than $95 \%$ of the emergences occurred during the interval from 1 December through 30 April, with a peak between January and March. The smooths of nesting data from Tartarugas and Andradas beaches (Fig. 2) show similar unimodal patterns among seasons. The mean track density on Tartarugas and Andradas was 3648 tracks $\mathrm{km}^{-1}$ (range: 1627 to 4938 ).

The first correction factor, the proportion of nests in relation to total tracks, was calculated from data for the 2 main beaches (Tartarugas and Andradas) obtained in 4 seasons (1999/2000, 2006/07, 2007/08, 2008/09). This proportion varied from 0.34 to 0.69 with a mean of 0.55 for Tartarugas and from 0.17 to 0.57 with a mean of 0.37 for Andradas (Table 2).

In the 3 seasons during which all beaches were monitored daily (1999/2000, 2006/07, and 2007/08), the 2 major beaches (Tartarugas and Andradas) had $54 \%$ of the tracks (range: 52.9 to $55.0 \%$ ) on the entire island. Therefore, the second correction factor, the relative proportion of nests on Tartarugas and Andradas relative to all 9 beaches on Trindade, was 0.54 .

We used the 2 correction factors to estimate the number of nests deposited annually on Trindade, which ranged from 1333 to 5261. Based on a least squares linear regression model with log link and autoregression (order 1) error structure (slope =

Table 2. Chelonia mydas. Proportions of nests in relation to total tracks on Tartarugas and Andradas, the 2 major beaches of Trindade Island, based on direct observations during 4 nesting seasons

\begin{tabular}{|lccccc|}
\hline \multirow{2}{*}{ Beach } & \multicolumn{5}{c|}{ Nesting season } \\
& $1999 / 2000$ & $2006 / 07$ & $2007 / 08$ & $2008 / 09$ & Mean \\
\hline Tartarugas & 0.572 & 0.687 & 0.340 & 0.586 & 0.546 \\
Andradas & 0.371 & 0.570 & 0.172 & 0.349 & 0.366 \\
\hline
\end{tabular}


0.0107, $\mathrm{p}=0.7896)$, there was no significant trend in the annual number of nests (Fig. 3).

The number of females nesting annually at a rookery can be estimated from the number of nests if the clutch frequency (mean number of clutches deposited
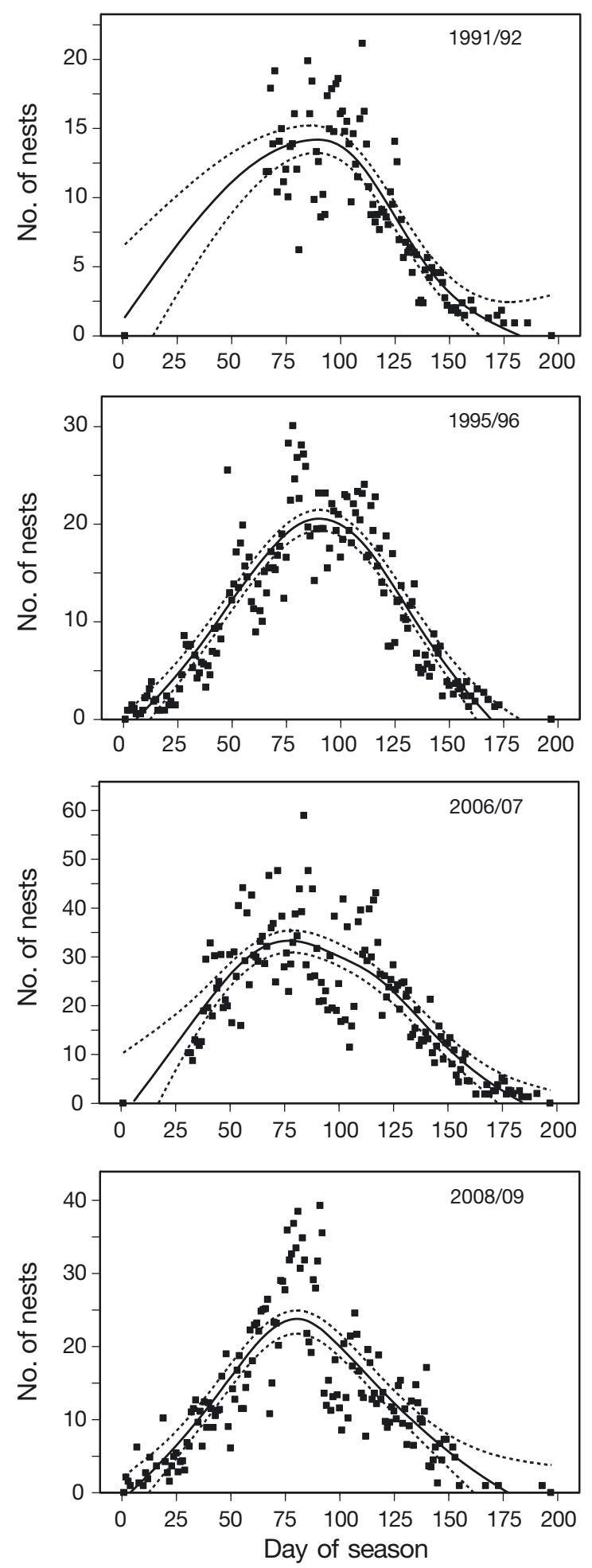

by individual females during the nesting season) is known. We do not know this value for Trindade, so we bracketed our estimate between 3 and 6 clutches per season (Troëng \& Rankin 2005). The mean annual number of nests on Trindade is 3600 . If clutch fre-
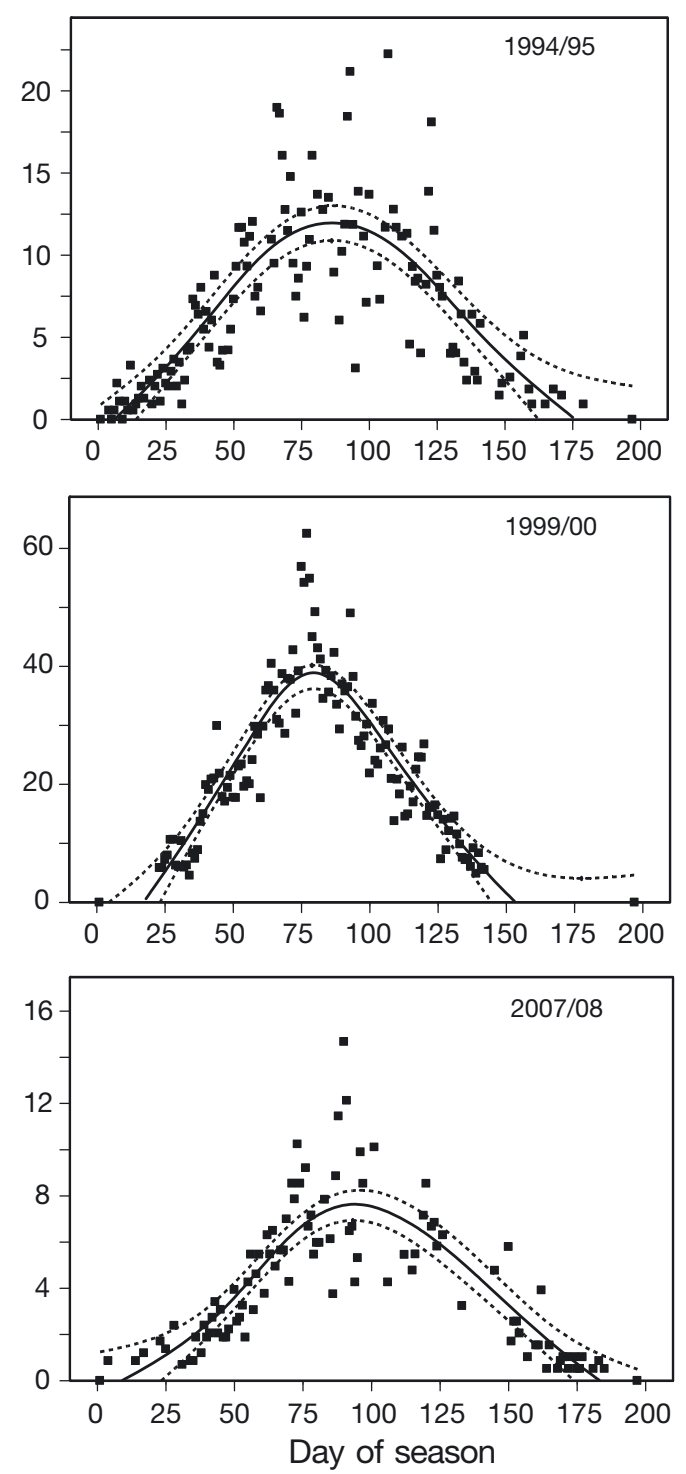

Fig. 2. Chelonia mydas. Estimated number of green turtle nests on Tartarugas and Andradas beaches (squares) with the smooth from the gam analyses (solid line) for the $7 \mathrm{yr}$ with good coverage. Dashed lines are \pm 2 SE. For day of season, Day 1 is 15 November and Day 197 is 30 May 


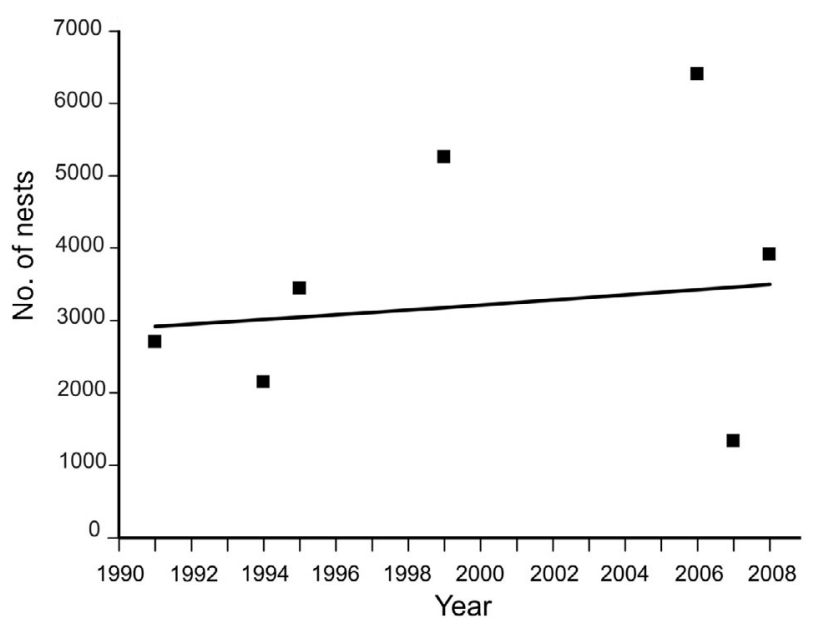

Fig. 3. Chelonia mydas. Annual estimates of green turtle nest numbers from all beaches on Trindade Island. Squares are annual estimates; line is the fit of the least squares regression model with a slope not significantly different from 0

quency is 3 , this nest count is equivalent to $1200 \mathrm{fe}-$ males nesting annually; if clutch frequency is 6 , this nest count is equivalent to 600 females.

\section{Biometrics}

From 1982 through 2009, CCLs of 3010 females were measured. Mean $( \pm \mathrm{SD}) \mathrm{CCL}$ was $115.2 \pm 5.8 \mathrm{~cm}$ (range: 90.0 to $143.5 \mathrm{~cm}$; median $=115 \mathrm{~cm}$ ).

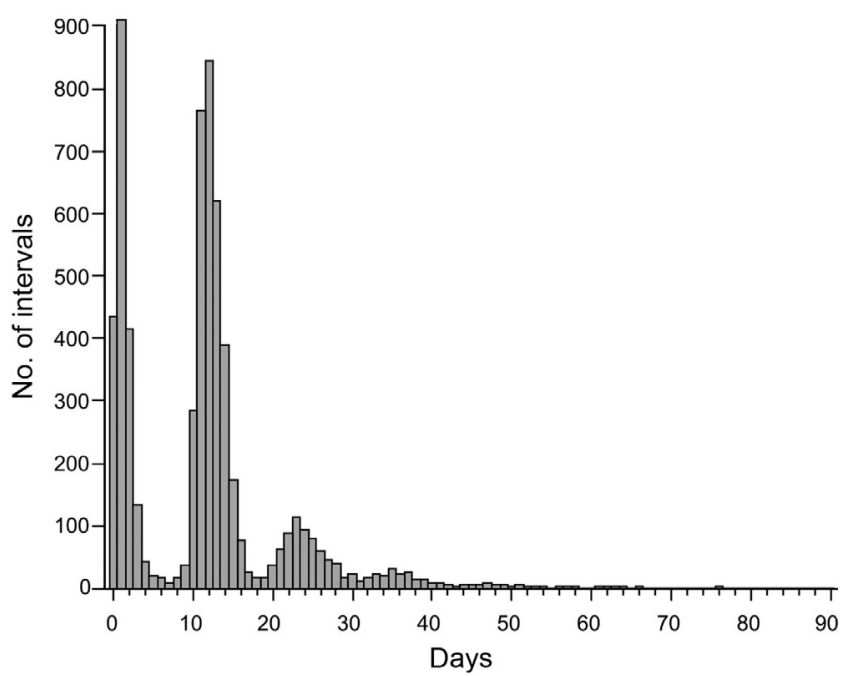

Fig. 4. Chelonia mydas. Number of days within a nesting season between successive sightings of green turtles nesting on Trindade Island $(\mathrm{n}=6954)$. Actual internesting intervals are probably 8 to $18 \mathrm{~d}$ (see 'Results')
Clutch size was obtained from 340 nests in 7 different seasons. We omitted 7 clutch size values ranging from 7 to 31 eggs from our analyses because they almost certainly represent interrupted or abnormal clutches. We used 43 eggs as the smallest normal clutch because this is the smallest value in a fairly continuous distribution; there is a 12-egg ' $g a p^{\prime}$ ' between 31 and 43 eggs. Based on 333 clutches, mean $( \pm \mathrm{SD})$ clutch size was $120.1 \pm 30.2$ eggs (range: 43 to 205 ; median $=119$ ).

From 1982 through 2009, 6954 internesting intervals were recorded on Trindade Island. Intervals between recaptures varied from 0 to $74 \mathrm{~d}$ (Fig. 4); the most common record $(n=1646)$ was $1 \mathrm{~d}$. Based on visual inspection of Fig. 4, we excluded intervals shorter than $8 \mathrm{~d}$ (which probably represent split egg clutches or a non-nesting emergence for the first record) and longer than $18 \mathrm{~d}$ (which probably represent missed clutches) for analyses. The intervals from 8 through $18 \mathrm{~d}$ had a mean of $12.3 \pm 1.6 \mathrm{~d}$ (median $=$ $12, \mathrm{n}=3254$ ).

Of the 3696 females tagged on the beaches of Trindade from 1982/83 through the 2008/09 season, 3458 females were not seen again after the tagging season; 238 females were recaptured at least once in subsequent seasons. Remigration intervals $(\mathrm{n}=263)$ varied from 2 to $16 \mathrm{yr}$, and $3 \mathrm{yr}$ was the most frequent interval (Fig. 5). We recorded 215 turtles in 2 different years, 21 turtles in 3 different years, and 2 turtles in 4 different years.

Maximum observed reproductive lifespan (years between first and last sighting) was 16 yr (1 female). Three females were re-encountered over $14 \mathrm{yr}$, and 26 over 13 yr.

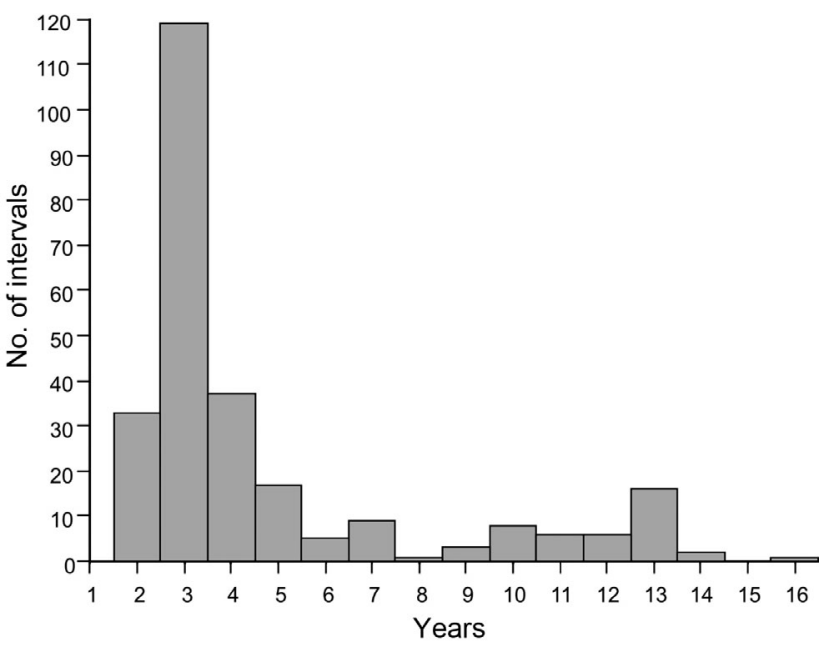

Fig. 5. Chelonia mydas. Remigration intervals recorded for green turtles nesting on Trindade Island $(\mathrm{n}=263)$ 
Hatching success was determined for 313 nests, and varied from 0 to $100 \%$ (mean: $84.4 \pm 21.5 \%$, median $=92.8 \%, \mathrm{n}=313$ ).

\section{DISCUSSION}

\section{Abundance and trends}

At many sea turtle nesting beaches, abundance is monitored by counting the tracks created by females when they come ashore (Troëng \& Rankin 2005, Witherington et al. 2009, National Research Council 2010). This technique is particularly important at remote rookeries or rookeries with a wide distribution of beaches that are difficult to access. Successful use of track counts to estimate abundance relies on distinguishing nesting emergences from non-nesting emergences. Some studies rely on experienced observers to distinguish between the 2 types of tracks while counting tracks (Mortimer \& Carr 1987, Bjorndal et al. 1999). Other studies have estimated the number of nests from track counts based on the proportion of nests relative to total tracks determined from a sub-sample of tracks (Godley et al. 2001, Catry et al. 2002, Weishampel et al. 2003). Because the proportion of nests to non-nesting emergences can vary for adjacent beaches (Godley et al. 2001) and for the same beach in different seasons (Weishampel et al. 2003), this assumption introduces some error. In our study, we used the latter approach, assuming that the proportion of nests to total tracks calculated for the 2 major beaches on Trindade was similar to that for the 7 remaining beaches.

The ratios of nests to total tracks for Trindade $(0.55$ for Tartarugas and 0.37 for Andradas) are within the range reported for Ascension Island. This ratio on the many beaches of Ascension ranged from 0.13 to 0.52 ; the overall ratio for Ascension Island calculated as total nests divided by total tracks was 0.39 (Godley et al. 2001). These relatively low values may well be a result of low sand moisture levels and sand particle sizes that hinder construction of nest cavities (Mortimer \& Carr 1987, Mortimer 1990, Godley et al. 2001). In addition to low sand moisture levels, turtles nesting on Trindade have to contend with large boulders on the beaches that interfere with nesting. The very high proportions of $0 \mathrm{~d}$ and $1 \mathrm{~d}$ renesting intervals coincide with the low ratio of nests to total tracks. Females must try to nest repeatedly on the same night and on successive nights before successfully depositing a clutch of eggs. For green turtles nesting at Tortuguero, Costa Rica, the ratio of nests to total tracks is higher, ranging from 33 to $74 \%$ (Tiwari 2004).

We estimate that the number of nests deposited on Trindade varied annually between 1333 in 2007/08 and 6402 in 2006/07 with a mean of 3600 for the duration of our study. This nest abundance places Trindade as the seventh largest nesting colony of green turtles in the Atlantic (Table 3). However, different techniques were used to estimate annual nest numbers for the different colonies, and several of the values are based only on $1 \mathrm{yr}$ of surveys, so the relative sizes of these colonies may change with additional surveys.

The number of nests on Trindade varied greatly among years (Fig. 3), particularly in the last 3 yr. This variation is characteristic of green turtle populations (Broderick et al. 2001, Chaloupka et al. 2008), and variation makes assessing population trends more challenging. However, based on the estimates from $7 \mathrm{yr}$ during the interval from 1991/92 through 2008/09, the population has been stable over this period.

Table 3. Chelonia mydas. Comparison of annual numbers of nests at major green turtle colonies in the Atlantic. Annual nests are either mean values or values from a single year

\begin{tabular}{|llll|}
\hline Colony site & Annual nests & Years sampled & Source \\
\hline Tortuguero, Costa Rica & 104411 & $1999-2003$ & Troëng \& Rankin (2005) \\
Ascension, UK & 11400 & $1999-2004$ & Broderick et al. (2006) \\
Florida, USA & 8808 & $2007-2009$ & FWCC (2011) \\
Bijagós Is., Guinea-Bissau & 7400 & 2000 & Catry et al. (2002) \\
Galibi, Suriname & 6313 & 1995 & Weijerman et al. (1998) \\
Yucatán, Mexico & $4641-9282^{\text {a }}$ & 2000 & Seminoff (2004) \\
Trindade, Brazil & 3600 & $1991 / 92-2008 / 09$ & Present study \\
Bioko Is., Equatorial Guinea & 1468 & $1996 / 97-1997 / 98$ & Tomás et al. (1999) \\
Aves Is., Venezuela & $1350-2700^{\text {a }}$ & 2006 & Vera (2008) \\
acalculated by multiplying the number of females per year by 3 and 6, respectively & \\
\hline
\end{tabular}




\section{Biometrics}

The mean CCL of nesting females from Trindade $(115.2 \mathrm{~cm})$ is among the largest reported for green turtle populations (Hirth 1997, Godley et al. 2002). Our results are similar to those reported earlier for Trindade (Moreira et al. 1995) based on a smaller sample size: $116.8 \mathrm{~cm}$ mean CCL, range 101.0 to 143.0, $\mathrm{n}=465$.

The mean clutch size (120.1 eggs) is nearly identical to the value of 120.9 eggs from a large sample of Ascension Island green turtle clutches $(\mathrm{n}=548$, Mortimer \& Carr 1987). The Trindade clutch size is an intermediate value compared to those reported for Atlantic populations (Hirth 1997). Because of the large body size of Trindade green turtles, the clutchsize-to-body-size value falls in the lower range of values for green turtles, as plotted by Hirth (1997).

Nests inventoried for hatching success were located in almost all cases by observing tracks left by hatchlings emerging from the nest. Thus, the values are hatching success of successful nests, not of all nests. There is an additional bias for nests with high success, because the probability of detection and the number of hatchlings emerging are almost certainly positively related. From these data, we cannot assess overall hatching success, and thus hatchling production, on Trindade. We can only conclude that beaches on Trindade provide an environment that can yield high hatching success. Determining overall hatching success and how that value varies among beaches on Trindade is important for future management and conservation purposes.

Remigration interval data must always be evaluated with care, particularly when surveys are incomplete and years omitted, as in the present study. Several factors can severely bias the remigration interval estimates. First, mortality (particularly in those populations with heavy human-induced mortality) will bias the estimates towards shorter intervals because the probability of an individual dying between reproductive seasons increases with length of remigration interval. Second, tag loss results in bias towards shorter intervals because the probability of tag loss (and thus missing an individual when it returns to nest in future years) increases with length of remigration interval. Third, incomplete surveys and skipped years bias the estimates towards longer intervals because the probability of missing a turtle increases with decreasing coverage.

However, even with the above provisos, it appears that, similar to many green turtle populations (Hirth 1997), 1 yr remigration intervals are very rare (none were recorded in our study), 3 yr intervals are the most common, and 2 and 4 yr intervals are also relatively common. Four year intervals may represent two 2 yr intervals for which the female was missed in the middle nesting season. We cannot determine whether the longer intervals represent missed intervening reproductive seasons or whether some females require substantially longer time intervals to accumulate the necessary fat and protein reserves to breed successfully.

Accurate estimates of reproductive lifespan (the number of years between first and last reproductive season) are beyond the scope of our study because of incomplete coverage, the total duration of our study (27 yr) from 1982/83 through 2008/09, and tag loss. Thus, our conclusions are limited to stating that the reproductive lifespan for Trindade turtles can reach at least $16 \mathrm{yr}$. We recorded 1 turtle with a 16 yr interval, 3 turtles with 14 yr intervals, and 26 turtles with $13 \mathrm{yr}$ intervals. All of the turtles with $13 \mathrm{yr}$ intervals were observed in 2 years (1995/96 and 2008/09), when major tagging efforts were made.

Monitoring of the Trindade green turtle population is continuing and will provide valuable information on the trend in abundance of this population. In addition, future studies based on genetic composition, satellite telemetry, and flipper tags will yield a better understanding of the foraging areas of this population.

Acknowledgements. We thank the Brazilian Navy (Marinha do Brasil, $1^{\circ}$ Distrito Naval), the volunteers who worked over the years collecting the data, and R. V. Alves who provided the climate data. Projeto TAMAR, a conservation program of the Brazilian Ministry of the Environment, is affiliated with ICMBio, co-managed by Fundação Pró-TAMAR and officially sponsored by PETROBRAS.

\section{LITERATURE CITED}

Almeida FFM (2002) Ilha de Trindade - registro de vulcanismo cenozóico no Atlântico Sul. In: Schobbenhaus C, Campos DA, Queiroz ET, Winge M, Berbert-Born MLC (eds) Sítios geológicos e paleontológicos do Brasil. DNPM/CPRM, Comissão Brasileira de Sítios Geológicos e Paleobiológicos (SIGEP), Brasília, p 369-377

Alves RJV (1998) Ilha da Trindade \& arquipélago Martin Vaz: um ensaio geobotânico, 1st edn. Serviço de Documentação da Marinha, Rio de Janeiro

Bellini C, Sanches TM (1996) Reproduction and feeding of marine turtles in the Fernando de Noronha Archipelago, Brazil. Mar Turtle Newsl 74:12-13

Bellini C, Marcovaldi MA, Sanches TM, Grossman A, Saks G (1996) Atol das Rocas Biological Reserve: second largest Chelonia rookery in Brazil. Mar Turtle Newsl 72:1-2

Bjorndal KA, Carr A (1989) Variation in clutch size and egg size in the green turtle nesting population at Tortuguero, Costa Rica. Herpetologica 45:181-189 
Bjorndal KA, Wetherall JA, Bolten AB, Mortimer JA (1999) Twenty-six years of green turtle nesting at Tortuguero, Costa Rica: an encouraging trend. Conserv Biol 13: 126-134

Bjorndal KA, Bolten AB, Moreira L, Bellini C, Marcovaldi MA (2006) Population structure and diversity of Brazilian green turtle rookeries based on mitochondrial DNA sequences. Chelonian Conserv Biol 5:262-268

Bolten AB (1999) Techniques for measuring sea turtles. In: Eckert KE, Bjorndal KA, Abreu-Grobois FA, Donnelly M (eds) Research and management techniques for the conservation of sea turtles. IUCN/SSC Marine Turtle Specialist Group Publication 4, Washington, DC, p 110-114

Bourjea J, Frappier J, Quillard M, Ciccione S, Roos D, Hughes G, Grizel H (2007) Mayotte Island: another important green turtle nesting site in the southwest Indian Ocean. Endang Species Res 3:273-282

> Broderick AC, Godley BJ, Hays GC (2001) Trophic status drives interannual variability in nesting numbers of marine turtles. Proc Biol Sci 268:1481-1487

Broderick AC, Frauenstein R, Glen F, Hays GC and others (2006) Are green turtles globally endangered? Glob Ecol Biogeogr 15:21-26

Carr A (1975) The Ascension Island green turtle colony. Copeia 1975:547-555

Catry P, Barbosa C, Indjai B, Almeida A, Godley BJ, Vie JC (2002) First census of the green turtle at Poilão, Bijagós Archipelago, Guinea-Bissau: the most important nesting colony on the Atlantic coast of Africa. Oryx 36:400-403

Chaloupka M, Bjorndal KA, Balazs GH, Bolten AB and others (2008) Encouraging outlook for recovery of a once severely exploited marine megaherbivore. Glob Ecol Biogeogr 17:297-304

DHN (Diretoria de Hidrografia e Navegação) (1968) Resumo histórico e origem da Ilha da Trindade. Departamento de GeofÍsica da Diretoria de Hidrografia e Navegação, Rio de Janeiro

Filippini A, Bulhões HA (1988) Estudo da ecologia da tartaruga marinha Chelonia mydas Linnaeus, na Ilha da Trindade. Bras Florest 65:5-15

FWCC (Florida Fish and Wildlife Conservation Commission) (2011) Fish and Wildlife Research Institute Marine Turtle Program - Statewide nesting totals 1979-2009. Available at http://research.myfwc.com/images/articles/11812/ statewide_totals_1979_-_2009.pdf (accessed 12 February 2011)

Gallo BMG, Macedo S, Giffoni B, Becker JH, Barata PCR (2006) Sea turtle conservation in Ubatuba, southeastern Brazil, a feeding area with incidental capture in coastal fisheries. Chelonian Conserv Biol 5:93-101

> Godley BJ, Broderick AC, Hays GC (2001) Nesting of green turtles Chelonia mydas at Ascension Island, South Atlantic. Biol Conserv 97:151-158

Godley BJ, Broderick AC, Frauenstein R, Glen F, Hays GC (2002) Reproductive seasonality and sexual dimorphism in green turtles. Mar Ecol Prog Ser 226:125-133

Hirth HF (1997) Synopsis of the biological data on the green turtle, Chelonia mydas (Linneaus 1758). USFWS Biol Rep 97, Washington, DC

> Lauret-Stepler M, Bourjea J, Roos D, Pelletier D, Ryan P, Ciccione S, Grizel H (2007) Reproductive seasonality and trend of Chelonia mydas in the SW Indian Ocean: a $20 \mathrm{yr}$ study based on track counts. Endang Species Res 3: $217-227$

Lima EHSM, Troëng S (2001) Link between green turtles foraging in Brazil and nesting in Costa Rica? Mar Turtle Newsl 94:9

> Marcovaldi MA, Chaloupka M (2007) Conservation status of the loggerhead sea turtle in Brazil: an encouraging outlook. Endang Species Res 3:133-143

Marcovaldi MA, Marcovaldi GG (1999) Marine turtles of Brazil: the history and structure of Projeto TAMARIBAMA. Biol Conserv 91:35-41

Miller JD (1999) Determining clutch size and hatching success. In: Eckert KE, Bjorndal KA, Abreu-Grobois FA, Donnelly M (eds) Research and management techniques for the conservation of sea turtles. IUCN/SSC Marine Turtle Specialist Group Publication 4, Washington, DC, p 124-129

Miranda LB, Castro Filho BM (1982) Geostrophic flow conditions of the Brazil Current at $19^{\circ} \mathrm{S}$. Cienc Interam 22: $44-48$

Moreira L, Baptistotte C, Scalfone J, Thomé JC, Almeida AP (1995) Occurrence of Chelonia mydas on the Island of Trindade, Brazil. Mar Turtle Newsl 70:2

Mortimer JA (1990) The influence of beach sand characteristics on the nesting behavior and clutch survival of green turtles (Chelonia mydas). Copeia 1990:802-817

Mortimer JA, Carr A (1987) Reproduction and migration of the Ascension Island green turtle (Chelonia mydas). Copeia 1987:103-112

National Research Council (2010) Assessment of sea-turtle status and trends: integrating demography and abundance. National Academies Press, Washington, DC

Penaloza C (2000) Demografia y viabilidad de la poblacion de tortuga verde, Chelonia mydas, en Isla de Aves. BSc thesis, Universidad Simon Bolivar, Sartenejas

Schulz JP (1975) Sea turtles nesting in Surinam. Zool Verh (Leiden) 143:3-172

Seminoff JA (2004) Chelonia mydas. In: IUCN Red List of Threatened Species. Version 2010.4. Available at www. iucnredlist.org (accessed on 12 February 2011)

Tiwari M (2004) Density-dependent effects on hatchling production in the green turtle nesting population in Tortuguero, Costa Rica. PhD dissertation, University of Florida, Gainesville

Tomás J, Castroviejo J, Raga JA (1999) Sea turtles in the south of Bioko Island (Equatorial Guinea). Mar Turtle Newsl 84:4-6

Troëng S, Rankin E (2005) Long-term conservation efforts contribute to positive green turtle Chelonia mydas nesting trend at Tortuguero, Costa Rica. Biol Conserv 121: $111-116$

Vera V (2008) Nesting of green turtles in Aves Island Wildlife Refuge, 2006 season. In: Rees AF, Frick M, Panagopoulou A, Williams K (comps) Proc 27th Annu Symp Sea Turtle Biol Conserv. NOAA Tech Memo NMFS-SEFSC-569, p 252

Weijerman M, van Tienen LHG, Schouten AD, Hoekert WEJ (1998) Sea turtles of Galibi, Suriname. In: Byles R, Fernandez Y (comps) Proc 16th Annu Symp Sea Turtle Biol Conserv. NOAA Tech Memo NMFS-SEFSC-412, p 142-144

Weishampel JF, Bagley DA, Ehrhart LM, Rodenbeck BL (2003) Spatiotemporal patterns of annual sea turtle nesting behaviors along an East Central Florida beach. Biol Conserv 110:295-303

Witherington B, Kubilis P, Brost B, Meylan AB (2009) Decreasing annual nest counts in a globally important loggerhead sea turtle population. Ecol Appl 19:30-54 